\title{
Effect of sodium stearoyl-2-lactylate supplementation on lactation performance, blood-biochemical profile, and economic efficacy of mid-lactation Holstein cows
}

\author{
Eun Tae Kim,a, Sang Suk Lee, ${ }^{2, a}$, Ji Hoon Lee ${ }^{3}$, Jin Suk Jeong ${ }^{3}$, Shin Ja Lee ${ }^{3}$, Joon Jeong ${ }^{4}$, Jong Kook Park ${ }^{4}$, \\ Beom Young Park', Sang Bum Kim ${ }^{1}$, Ha Yeon Jeong ${ }^{1}$, Kwang Seok Ki ${ }^{1}$, Chang Weon Choi ${ }^{5}$, \\ Chang Hyun $\mathrm{Kim}^{6}$, Jin Wook Kim${ }^{3}$, and Sung Sill Lee,*
}

\footnotetext{
* Corresponding Author: Sung Sill Lee Tel: +82-55-772-1883, Fax: +82-55-772-1889,

E-mail: Iss@gnu.ac.kr

${ }^{1}$ National Institute of Animal Science, Rural Development Administration, Cheonan 31000, Korea 2 Department of Animal Science and Technology, Sunchon National University, Suncheon 57922, Korea ${ }^{3}$ Division of Applied Life Science (BK21 Plus), Gyeongsang National University, IALS, Jinju 52825 , Korea

${ }^{4}$ Livestock Research Institute, National Agricultural Cooperative Federation, Anseong 17558, Korea ${ }^{5}$ Department of Animal Resources, Daegu University, Gyeongsan 38453, Korea

${ }^{6}$ Department of Animal Life and Environment Science, Hankyong National University, Anseong 17579, Korea

a These authors contributed equally to the work.
}

\section{ORCID}

Eun Tae Kim

https://orcid.org/0000-0001-7486-5638 Sang Suk Lee

https://orcid.org/0000-0001-8804-3416 Ji Hoon Lee

https://orcid.org/0000-0002-9953-2706 Jin Suk Jeong

https://orcid.org/0000-0001-6877-3067 Shin Ja Lee

Shin Ja Lee
https://orcid.org/0000-0002-4224-1211 Joon Jeong

https://orcid.org/0000-0002-7666-4757 Jong Kook Park

https://orcid.org/0000-0002-9959-0578 Beom Young Park

https://orcid.org/0000-0002-0604-7569 Sang Bum Kim

https://orcid.org/0000-0002-8187-4134 Ha Yeon Jeong

https://orcid.org/0000-0001-5253-2584 Kwang Seok Ki

https://orcid.org/0000-0003-0971-1389 Chang Weon Choi

https://orcid.org/0000-0001-7681-5335 Chang Hyun Kim

https://orcid.org/0000-0001-6325-9755

https://orcid.

Jin Wook Kim

Sung Sill Lee

https://orcid.org/0000-0002-4621-4333

Submitted May 10, 2018; Revised Jun 19, 2018; Accepted Jul 16, 2018
Objective: This study was done to evaluate the effect of sodium stearoyl-2-lactylate (SSL) supplementation in a total mixed ration (TMR) on the lactation performance, blood parameters, and economic efficacy of mid-lactation Holstein cows.

Methods: Twenty-four cows (body weight $647 \pm 11.7 \mathrm{~kg}$ ) were randomly divided into 4 treatment groups, with six cows per group. The dietary treatments were as follows: basal diet (CON); CON+17.5 g of top dressed SSL (treatment [TRT] 0.05); CON+35 g of SSL (TRT 0.1 ); and CON+70 g of SSL (TRT 0.2) per $35 \mathrm{~kg}$ TMR.

Results: The highest level of SSL supplementation (TRT 0.2) significantly improved milk yield during the second period compared to the TRT 0.05 group ( 5 to 8 wks; 33.28 vs 31.09 $\mathrm{kg} / \mathrm{d})$, during the third period compared to both the CON and TRT 0.05 groups $(\mathrm{p}<0.05)$ ( 9 to $13 \mathrm{wks;} 32.59$ vs 30.64 and $30.01 \mathrm{~kg} / \mathrm{d}$ ) and during the overall experimental period compared to both the CON and TRT 0.05 groups ( $\mathrm{p}<0.05$ ) ( 1 to $13 \mathrm{wks} ; 33.43$ vs 32.06 and 31.40 $\mathrm{kg} / \mathrm{d}$ ), respectively. No negative effects on hematological or biochemical parameters were observed due to SSL supplementation. Considering both the milk fat and protein content, the total milk price was set at 1,073.60 (TRT 0.05), 1,085.60 (TRT 0.1), 1,086.10 (TRT 0.2), and $1,064.20(\mathrm{CON})$ won/L, with consequent total milk profits of $-1.7 \%, 5.4 \%$, and $3.5 \%$ for the TRT 0.05, TRT 0.1, and TRT 0.2 diet, respectively, compared to those in the CON diet. Conclusion: The milk sales revenue related to SSL supplementation of the TRT 0.1 diet was increased by up to $5.4 \%$ compared to the milk sales revenue of the CON diet. Therefore, $0.1 \%$ SSL supplementation might be effective and profitable during the mid-lactation period of cows, without producing adverse effects.

Keywords: Sodium Stearoyl Lactylate; Holstein Cows; Blood Parameters; Economic Efficacy; Lactation Performance

\section{INTRODUCTION}

Recent generations of cows have been improved to produce high lactation yields through selective breeding and enhanced animal management. However, nutritional and physical imbalances during the early lactation period can be easily occurred in dairy cows. Feeding management for high-producing dairy cows during pre-calving and post-calving periods impacts animal performance [1]. Enhancing lipid use can improve feed efficacy and animal productivity while reducing feed costs, as fat is an essential nutrient with the highest energy density among the major macronutrients [2]. Lipids are commonly used to improve feed energy for high yield cows, and adding them to the feed has many benefits, such as improved 
fat-soluble nutrient absorption (i.e., essential fatty acids, vitamin $\mathrm{A}, \mathrm{D}, \mathrm{E}$, and $\mathrm{K}$ ), increased palatability, and reduction of feed dust [3]. Many studies have investigated methods for improving lipid use in ruminants [4-6]. Some studies have focused on surfactant supplementation for emulsification [7-10]; for example, beneficial effects of surfactants have been observed on ruminal fermentation as well as animal performance. However, the response to surfactants is not always positive, as shown by Hristov et al [11] and Wang et al [12]. Dietary lipids must be broken down into smaller structures to be absorbed in the small intestine. Zinn [13] and Cho et al [14] suggested that increased surface area and micelle number can help determine the rate and extent of lipid hydrolysis, which can improve lipid digestibility and fat yield in cattle supplemented with surfactants. Furthermore, lipids in an oilin-water state within the small intestine undergo a different absorption process than hydrophilic carbohydrates and proteins. Thus, to efficiently digest and absorb lipids, oil-in-water system surfactants, such as sodium stearoyl lactylate (SSL), act as positive emulsifiers compared to water-in-oil system surfactants, such as lecithin [15], and can resolve immiscibility and provide stability to an oil-water system. The hydrophiliclipophilic balance in SSL is between 10 and 12, which indicates that SSL is an excellent emulsifier to facilitate the formation of fat in water emulsions for lipid digestion in the small intestine, thus leading to emulsion stability [16]. Therefore, this study was under taken to ascertain the effect of SSL supplementation in a total mixed ration (TMR) diet on the lactation performance, blood parameters, and economic efficacy of midlactation Holstein cows.

\section{MATERIALS AND METHODS}

\section{Animal care}

All experimental procedures performed in this study were approved by the Animal Care Committee of Gyeongsang National University (Jinju, Gyeongsangnam-do, Republic of Korea).

\section{Animals, diets and management}

A total of twenty-four lactating Holsteins cows, with an initial body weight of $647 \pm 11.7 \mathrm{~kg}$ (mean \pm standard deviation) and parity of $2.3 \pm 0.30$ were randomly divided into 4 treatment groups with six cows per treatment. The dietary treatments included the following: CON, basal diet; treatment (TRT) 0.05 , $\mathrm{CON}+17.5 \mathrm{~g}$ of top dressed SSL; TRT 0.1, CON+35 g of SSL; and TRT $0.2, \mathrm{CON}+70 \mathrm{~g}$ of SSL per $35 \mathrm{~kg}$ of TMR. All experimental diets were formulated to meet or exceed NRC [17] recommendations for a $650-\mathrm{kg}$ cow producing $33 \mathrm{~kg} / \mathrm{d}$ of milk, with $4.0 \%$ fat and $3.4 \%$ protein, regardless of treatment. Cows were fed twice per day at 06:00 $\mathrm{h}$ and 18:00 $\mathrm{h}$ in their stalls and supplemented with SSL as the top dressing of the basal ration. After a 7-day adaptation period, the animals were exposed to the different treatments for the entire experimental period. The animals were placed in an environmentally regulated facility and provided ad libitum access to water throughout the 98-day experimental period. Experimental diet samples were dried in a forced-air oven at $130^{\circ} \mathrm{C}$ for $2 \mathrm{~h}$, after being finely ground through a 2-mm screen in a Wiley mill (Model 4, Thomas Scientific, Swedesboro, NJ, USA). The ground samples were analyzed to determine the amounts of dry matter, crude protein, $\mathrm{Ca}$, and $\mathrm{P}$ according to the AOAC procedure [18]. Ether extraction was performed by the diethyl ether extraction method using a Buchi B-811 Universal Extraction System (Buchi, Flawil, Switzerland). Crude fiber was analyzed by the filter bag technique using the ANKOM 220 Fiber Analyzer (Mill Tech, Seongnam, Korea), and ash was analyzed by an electric muffle furnace using a KMF-500 (Lab Corporation, Seoul, Korea) after burning at $550^{\circ} \mathrm{C}$. The concentration of neutral detergent fiber, which includes cellulose, hemicellulose and lignin as the major components, corrected for residual ash, was determined with thermostable alphaamylase using the method of Van Soest et al [19], while the concentration of acid detergent fiber (Method 973.18), with inclusion of residual ash, was determined according to the AOAC procedure [18]. The net energy of lactation is the energy required for lactation and maintenance [17], and this was calculated using the metabolic energy from the apparent total tract digestibility of the digestible protein, fat and carbohydrates. The characteristics of the experimental animals, TMR ingredients and chemical compositions are shown in Table 1.

\section{Sampling, measurements and chemical analysis}

The animals were milked twice per day at 05:00 and 17:00 for the first 13 weeks, and the daily milk yield was recorded daily using a Milk Meter (TRU-TEST Ltd., Central Otago, New Zealand). Milk samples from both morning and evening milking were collected once every 3 weeks and analyzed to determine fat, protein, lactose, solids-non-fat (SNF), and milk urea nitrogen (MUN) content using a Speedy Lab (Astorilab, Poncarale, Italy), as shown in Table 2. Blood samples were obtained by direct venipuncture of the jugular vein at the end of the experimental period, prior to the morning feeding. Whole blood samples $(6 \mathrm{~mL})$ were collected in $10 \mathrm{~mL} \mathrm{BD}$ vacuum tubes with sodium heparin (Becton and Dickinson, NJ, USA). After clotting at $4^{\circ} \mathrm{C}$ for $24 \mathrm{~h}$, serum analysis samples were centrifuged at $2,500 \times \mathrm{g}$ at $4^{\circ} \mathrm{C}$ for $30 \mathrm{~min}$, separated, and stored at $-70^{\circ} \mathrm{C}$ until further analysis. Blood samples were analyzed using a Hitachi 7020 automatic blood analyzer (Hitachi, Tokyo, Japan). Whole blood samples were used to measure hematological parameters including the white blood cell (WBC) count, red blood cell (RBC) count, hemoglobin content and hematocrit value. Plasma blood samples were used 
Table 1. Ingredients and chemical composition of experimental total mixed ration (TMR) diets

\begin{tabular}{lc}
\hline Item & Value $\mathbf{( g / k g )}$ \\
\hline Ingredients, as-fed basis & 20 \\
Corn grain & 67 \\
Cotton seed & 260 \\
TMR granules & 37 \\
Soybean meal & 90 \\
Alfalfa hay & 60 \\
Beet pulp & 100 \\
Oat hay & 90 \\
Timothy hay & 2 \\
Limestone & 2 \\
Salt & 2 \\
NaHCO & \\
Water & 270 \\
Chemical composition, as-fed basis & \\
Dry matter & 579.1 \\
Crude protein & 156.3 \\
Crude fat & 43.6 \\
Crude fiber & 192.3 \\
Total ash & 83.8 \\
Calcium & 8.9 \\
Phosphorus & 4.6 \\
Neutral detergent fiber & 414.6 \\
Acid detergent fiber & 218.7 \\
Net energy of lactation (cal/kg) & 1,560 \\
\hline
\end{tabular}

to measure the chemical composition of the plasma including the total protein, albumin, glucose, aspartate aminotransferase, alanine aminotransferase (ALT), gamma glutamyl transferase, blood urea nitrogen, creatinine, total triglycerides, non-esterified fatty acid, and cholesterol concentrations [20,21].

\section{Economic efficacy analysis}

The TMR price as fed dry matter was set at $600 \mathrm{won} / \mathrm{kg}$, and lactating feed was set to $764 \mathrm{won} / \mathrm{kg}$ with $87 \%$ total digestible nutrients and $18 \%$ crude protein based on the standard of milk pricing concept from the Korea Dairy Committee [22]. The economic analysis was conducted based on the cost of feed intake and the price of milk yield. The total feed and milk costs did not include basic costs such as labor, equipment, materials, energy and water.

\section{Statistical analysis}

All data for cows within each treatment group were averaged and analyzed using the PROC GLM procedure in SAS [23] with the following statistical model: $\mathrm{Y}_{\mathrm{ij}}=\mu+\mathrm{TRT}_{\mathrm{i}}+\mathrm{e}_{\mathrm{ij}}$, where $\mathrm{Y}_{\mathrm{ij}}$ is an observation on the dependent variable $\mathrm{ij}, \mu$ is the overall population mean, $\mathrm{TRT}_{\mathrm{i}}$ is the fixed effect of treatments, and $\mathrm{e}_{\mathrm{ij}}$ is the random error associated with the observation ij. Duncan's multiple range test [24] was used to determine significant differences among the mean values of the treatments.
Table 2. Effects of sodium stearoyl-2-lactylate (SSL) on milk yield and milk composition of Holstein cows

\begin{tabular}{|c|c|c|c|c|c|}
\hline \multirow{2}{*}{ Item } & \multicolumn{4}{|c|}{ Treatments $^{1)}$} & \multirow{2}{*}{ SEM } \\
\hline & CON & TRT 0.05 & TRT 0.1 & TRT 0.2 & \\
\hline \multicolumn{6}{|l|}{ Milk yield (kg/d) } \\
\hline On-test yield & 34.25 & 34.17 & 34.23 & 34.05 & 0.118 \\
\hline 1 to 4 weeks & 33.59 & 33.10 & 33.88 & 34.43 & 0.113 \\
\hline 5 to 8 weeks & $31.96^{\mathrm{ab}}$ & $31.09^{b}$ & $32.98^{\mathrm{ab}}$ & $33.28^{\mathrm{a}}$ & 0.204 \\
\hline 9 to 13 weeks & $30.64^{b}$ & $30.01^{b}$ & $32.30^{\mathrm{a}}$ & $32.59^{\mathrm{a}}$ & 0.256 \\
\hline Overall & $32.06^{b}$ & $31.40^{b}$ & $33.05^{\mathrm{ab}}$ & $33.43^{\mathrm{a}}$ & 0.189 \\
\hline \multicolumn{6}{|l|}{ Milk composition } \\
\hline Fat (\%) & $3.95^{\mathrm{b}}$ & $4.14^{\mathrm{a}}$ & $4.15^{\mathrm{a}}$ & $3.90^{\mathrm{b}}$ & 0.026 \\
\hline Fat yield (kg/d) & $1.29^{b}$ & $1.29^{b}$ & $1.40^{\mathrm{a}}$ & $1.30^{\mathrm{b}}$ & 0.011 \\
\hline Protein (\%) & $3.37^{b}$ & $3.50^{\mathrm{a}}$ & $3.48^{\mathrm{a}}$ & $3.33^{b}$ & 0.017 \\
\hline Protein yield (kg/d) & 1.10 & 1.08 & 1.17 & 1.08 & 0.009 \\
\hline Lactose (\%) & 4.49 & 4.43 & 4.49 & 4.42 & 0.008 \\
\hline Lactose yield (kg/d) & 1.46 & 1.36 & 1.51 & 1.39 & 0.014 \\
\hline SNF $(\%)$ & 8.59 & 8.63 & 8.87 & 8.62 & 0.026 \\
\hline MUN (mg/dL) & $14.27^{\mathrm{a}}$ & $14.89^{\mathrm{a}}$ & $12.96^{b}$ & $14.49^{\mathrm{a}}$ & 0.171 \\
\hline
\end{tabular}

Variability in the data was expressed as the standard error of the mean; a value of $\mathrm{p}<0.05$ was considered statistically significant, and a value of $\mathrm{p}<0.10$ was considered a tendency.

\section{RESULTS AND DISCUSSION}

\section{Lactation performance}

The milk yield and milk composition of mid-lactation cows supplemented with different amounts of SSL are shown in Table 2. The highest level of SSL supplementation (TRT 0.2) significantly improved milk yield during the second period compared to the TRT 0.05 group ( 5 to 8 wks; 33.28 vs 31.09 $\mathrm{kg} / \mathrm{d}$ ), during the third period compared to both the $\mathrm{CON}$ and TRT 0.05 groups $(\mathrm{p}<0.05$ ) ( 9 to 13 wks; 32.59 vs 30.64 and $30.01 \mathrm{~kg} / \mathrm{d}$ ) and during the overall experimental period compared to both the CON and TRT 0.05 groups $(\mathrm{p}<0.05)$ ( 1 to 13 wks; 33.43 vs 32.06 and $31.40 \mathrm{~kg} / \mathrm{d}$ ), respectively. Consequently, milk yield increased with increased amounts of SSL supplementation for the overall experimental period compared to that for the starting period (on-test yield; -2.19 in the CON group, -2.77 in the TRT 0.05 group, -1.18 in the TRT 0.1 group, and $-0.8 \mathrm{~kg}$ in the TRT 0.2 group). In vitro ruminal studies $[4-7,10]$ have demonstrated that supplemented nonionic surfactants can enhance ruminal fermentation and improve feed efficiency due to their stimulatory effects on ruminal stability, ruminal microorganism numbers, growth performance, enzyme accessibility and synergy between cellulase and xylanase. For example, enhanced microbial growth 
can increase the amount of fibrolytic enzymes such as cellulase and xylanase, produced by rumen microorganisms, which could then increase acetate production as milk fat synthesis precursors increase and become converted to milk fat percentages. In our study, SSL supplementation (TRT 0.1) significantly improved the fat percentage compared to that of the CON and TRT 0.2 groups $(4.15 \%$ vs $3.95 \%$ and $3.90 \%$, respectively) and the fat yield compared to that of the CON, TRT 0.05 , and TRT 0.2 groups (1.41 vs $1.29,1.29$ and $1.30 \mathrm{~kg} / \mathrm{d}$, respectively) $(\mathrm{p}<0.05)$. These results are consistent with those of previous studies by Dierick and Decuypere [25], demonstrating that SSL supplementation can significantly improve and promote milk fat synthesis to increase the fat percentage. Moreover, surfactant supplementation increased the amount of fatty acids from dietary lipids and improved their absorption in the small intestine. SSL supplementation (TRT 0.1) also improved the protein percentage compared to that of the TRT 0.2 group ( 3.48 vs $3.33 \mathrm{~kg} / \mathrm{d}$ ), which is consistent with the results of a previous study by Dickinson [26,27]. That study suggested that ionic surfactants had a relatively higher affinity for absorption by the interfacial protein, which could cause the protein network to be more easily disrupted, resulting in stronger electrostatic interactions than those formed by a nonionic surfactant. Conversely, SSL supplementation (TRT 0.1) significantly reduced the MUN percentage compared to that of the CON, TRT 0.05 and TRT 0.2 groups ( $12.96 \%$ vs $14.27 \%$, $14.89 \%$ and $14.49 \%$, respectively) ( $\mathrm{p}<0.05)$. This result suggests that the TRT $0.1 \operatorname{diet}$ ( $35 \mathrm{~g}$ of SSL per $35 \mathrm{~kg}$ TMR) provided optimal microbial protein synthesis compared to the other treatments, even though all data were within the normal range (12 to $16 \mathrm{mg} / \mathrm{dL}$ ) [28], indicating that sufficient carbohydrate amounts were provided for optimal rumen function and microbial synthesis [29]. However, SSL supplementation had no effect on the protein yield, lactose percentage, lactose yield or SNF content $(\mathrm{p}>0.10)$.

\section{Blood parameters}

The hematological and biochemical blood parameters of midlactation cows supplemented with different SSL levels are shown in Table 3. Blood profiling is considered a significant indicator of nutrient status and body condition, and comparison of blood metabolites may help to diagnose and prevent metabolic disorders [30,31]. The most common blood diagnostic test is the complete blood count, which includes the WBC count, RBC count, hemoglobin content, and hematocrit value. No significant differences were observed among the treatments in the current study ( $p>0.05)$. All values were within the normal range, indicating that no significant changes were induced by the environmental and dietary adaptation of the cows [32]. The blood biochemical parameters, which evaluate the function of different organs including the kidneys and liver, and internal metabolic changes in cattle [33], showed
Table 3. Effects sodium stearoyl-2-lactylate (SSL) on hematological and biochemical parameters of Holstein cows

\begin{tabular}{|c|c|c|c|c|c|}
\hline \multirow{2}{*}{ Item } & \multicolumn{4}{|c|}{ Treatments ${ }^{1)}$} & \multirow{2}{*}{ SEM } \\
\hline & CON & TRT 0.05 & TRT 0.1 & TRT 0.2 & \\
\hline \multicolumn{6}{|l|}{ Hematological parameters } \\
\hline White blood cells $(\mathrm{K} / \mu \mathrm{L})$ & 12.6 & 13.9 & 10.6 & 15.2 & 0.40 \\
\hline Red blood cells (M/ $\mu \mathrm{L})$ & 6.7 & 6.6 & 6.8 & 6.5 & 0.03 \\
\hline Hemoglobin (g/dL) & 10.6 & 10.5 & 10.5 & 10.2 & 0.04 \\
\hline Hematocrit $(\mathrm{g} / \mathrm{dL})$ & 30.8 & 30.5 & 30.3 & 29.2 & 0.14 \\
\hline \multicolumn{6}{|l|}{ Biochemical parameters } \\
\hline Total protein (g/dL) & 8.3 & 8.2 & 8.3 & 8.6 & 0.17 \\
\hline Albumin $(\mathrm{g} / \mathrm{dL})$ & $4.1^{\mathrm{a}}$ & $3.9^{b}$ & $4.0^{\mathrm{ab}}$ & $4.1^{\mathrm{a}}$ & 0.10 \\
\hline Glucose (mg/dL) & 62.1 & 61.9 & 65.6 & 62.8 & 1.71 \\
\hline AST (IU/L) & 91.6 & 103.8 & 93.1 & 94.4 & 5.50 \\
\hline $\operatorname{ALT}(\mathrm{IU} / \mathrm{L})$ & $39.8^{b}$ & $48.5^{\mathrm{a}}$ & $40.1^{b}$ & $41.7^{b}$ & 4.07 \\
\hline $\mathrm{GGT}(\mathrm{mg} / \mathrm{dL})$ & 26.7 & 27.0 & 24.1 & 29.4 & 0.44 \\
\hline Total bilirubin (mg/dL) & 0.3 & 0.3 & 0.4 & 0.3 & 0.09 \\
\hline BUN (mg/dL) & 20.4 & 20.9 & 19.6 & 21.4 & 0.77 \\
\hline Creatinine (mg/dL) & 0.9 & 0.9 & 0.9 & 0.9 & 0.01 \\
\hline Total glyceride, (mg/dL) & 16.1 & 14.9 & 17.5 & 14.5 & 1.35 \\
\hline NEFA ( $\mu \mathrm{Eq} / \mathrm{L})$ & 219.3 & 205.0 & 240.2 & 212.4 & 2.95 \\
\hline Cholesterol (mg/dL) & 304.1 & 328.8 & 306.9 & 288.2 & 3.41 \\
\hline
\end{tabular}

SEM, standard error of the mean; AST, aspartate aminotransferase; ALT, alanine aminotransferase; GGT, gamma glutamyl transferase; BUN, blood urea nitrogen; NEFA, non-esterified fatty acid; TMR, total mixed ration.

1) CON, basal diet; TRT $0.05,17.5 \mathrm{~g}$ of SSL per $35 \mathrm{~kg}$ TMR; TRT $0.1,35 \mathrm{~g}$ of SSL per $35 \mathrm{~kg}$ TMR; TRT $0.2,70 \mathrm{~g}$ of SSL per $35 \mathrm{~kg}$ TMR.

${ }^{a b}$ Means with different superscripts within the same row differ $(p<0.05)$.

no significant differences among the treatments ( $\mathrm{p}>0.05)$. The exceptions were the albumin and ALT values, in which SSL supplementation via the TRT 0.05 diet (17.5 $\mathrm{g}$ of SSL per 35 $\mathrm{kg}$ TMR) resulted in lower albumin $(3.9 \mathrm{~g} / \mathrm{dL})$ and higher ALT $(48.5 \mathrm{IU} / \mathrm{L})$ values than those of the CON group $(4.1 \mathrm{~g} / \mathrm{dL}$ and $39.8 \mathrm{IU} / \mathrm{L}$, respectively) $(\mathrm{p}<0.05)$. However, the values of these measures were within the normal range as previously reported by Mohamed [34]. These results indicated that low-level SSL supplementation (TRT 0.05) might be insufficient to improve ruminal microbial protein synthesis and protein absorption, as shown by lower albumin values than those of the other treatments [35], and liver function of mid-lactation cows, as shown by the highest ALT value among the treatments [36]. The effect of SSL supplementation on hematological and biochemical parameters remains unclear.

\section{Economic efficacy}

The economic efficacy of SSL supplementation is shown in Table 4 . The total feed costs per head including TMR, concentrate and SSL were increased by $0.8 \%, 1.5 \%$, and $3.1 \%$ for the TRT 0.05 , TRT 0.1 , and TRT 0.2 diets, respectively, compared to those in the CON diet. All milk samples were evaluated as grade $1 \mathrm{~A}$ (in Korea), meaning that the raw milk included less than 30,000 bacterial $\mathrm{cfu} / \mathrm{mL}$ and less than 200,000 somatic cells/mL (data not shown) [22]. Furthermore, milk yield 
Table 4. Effects of sodium stearoyl-2-lactylate (SSL) on the economic efficacy of Holstein cows

\begin{tabular}{|c|c|c|c|c|}
\hline \multirow{2}{*}{ Item } & \multicolumn{4}{|c|}{ Treatments ${ }^{1)}$} \\
\hline & CON & TRT 0.05 & TRT 0.1 & TRT 0.2 \\
\hline $\begin{array}{l}\text { A. Total feed cost } \\
\text { (US } \$ / 305 \mathrm{~d} / \text { head) }\end{array}$ & $2,591.02$ & $2,611.00$ & $2,630.97$ & $2,670.92$ \\
\hline TMR & $2,300.33$ & $2,300.33$ & $2,300.33$ & $2,300.33$ \\
\hline Concentrate & 290.69 & 290.69 & 290.69 & 290.69 \\
\hline SSL & 0.00 & 11.66 & 39.35 & 79.90 \\
\hline $\begin{array}{l}\text { B. Total milk price } \\
\text { (US } \$ / 305 \text { d/head) }\end{array}$ & $8,731.02$ & $8,646.86$ & $9,105.42$ & $9,024.66$ \\
\hline Milk yield & 9,778 & 9,577 & 10,080 & 10,196 \\
\hline Milk price & 0.89 & 0.90 & 0.90 & 0.89 \\
\hline $\begin{array}{l}\text { B-A. Profit } \\
\text { (US \$/head) }\end{array}$ & $6,140.00$ & $6,035.86$ & $6,474.45$ & $6,353.74$ \\
\hline Index (\%) & 100.0 & 98.3 & 105.4 & 103.5 \\
\hline
\end{tabular}

and components (milk fat and protein content) are important for determining milk price and indicating whether animal health or nutritional management problems exist. Considering both the milk fat and protein content, the total milk price was set at 1,073.60 (TRT 0.05), 1,085.60 (TRT 0.1), 1,086.10 (TRT 0.2), and 1,064.20 (CON) won/L, with consequent total milk profits of $-1.7 \%, 5.4 \%$, and $3.5 \%$ for the TRT 0.05 , TRT 0.1 , and TRT 0.2 diet, respectively, compared to those in the CON diet. Based on these results, SSL supplementation (TRT 0.1 ) during the mid-lactation period of cows may increase profits.

\section{CONCLUSION}

The results demonstrated that SSL supplementation using a TRT 0.1 diet could improve milk yield and milk composition (higher fat and protein content with a lower MUN concentration) compared to a CON diet. Consequently, the milk sales revenue related to SSL supplementation of the TRT 0.1 diet was increased by up to $5.4 \%$ compared to the milk sales revenue of the CON diet. Therefore, $0.1 \%$ SSL supplementation might be effective and profitable during the mid-lactation period of cows, without producing adverse effects. However, further study is needed to better understand how SSL supplementation will affect ruminal fermentation and blood metabolites in mid-lactation Holstein cows.

\section{CONFLICT OF INTEREST}

We certify that there is no conflict of interest with any financial organization regarding the material discussed in the manuscript.

\section{ACKNOWLEDGMENTS}

This work was carried out with the support of "Cooperative Research Program for Agriculture Science \& Technology Development (Project No. PJ01269703)" Rural Development Administration, Republic of Korea. Eun Tae Kim was supported by the RDA Fellowship Program of National Institute of Animal Science, Rural Development Administration, Republic of Korea.

\section{REFERENCES}

1. Drackley JK, Cardoso FC. Prepartum and postpartum nutritional management to optimize fertility in high-yielding dairy cows in confined TMR systems. Animal 2014;8:5-14.

2. Drewnowski A. Obesity and the food environment: Dietary energy density and diet costs. Am J Prev Med 2004;27:154-62.

3. Staples CR, Cullens FM. Implications of fat-feeding practices for lactating dairy cows-effects on milk fat. Adv Dairy Technol 2005;17:277-95.

4. Akin DE. Evaluation by electron microscopy and anaerobic culture of types of rumen bacteria associated with digestion of forage cell walls. Appl Environ Microbiol 1980;39:242-52.

5. Lee SS, Ahn BH, Kim HS, et al. Effects of non-ionic surfactants on enzyme distributions of rumen contents, anaerobic growth of rumen microbes, rumen fermentation characteristics and performances of lactating cows. Asian-Australas J Anim Sci 2003;16:104-15.

6. Lee SS, Ha JK. Influences of surfactant tween 80 on the gas production, cellulose digestion and enzyme activities by mixed rumen microorganisms. Asian-Australas J Anim Sci 2003;16: 1151-7.

7. Goto M, Bae H, Lee SS, et al. Effects of surfactant Tween 80 on forage degradability and microbial growth on the in vitro rumen mixed and pure cultures. Asian-Australas J Anim Sci 2003;16:672-6.

8. Kim C-H, Kim JN, Ha JK, Yun SG, Lee SS. Effects of dietary addition of surfactant tween 80 on ruminal fermentation and nutrient digestibility of Hanwoo steers. Asian-Australas J Anim Sci 2004;17:337-42.

9. Ahn G-C, Kim J-H, Park E-K, et al. Effects of non-ionic surfactant supplementation on ruminal fermentation, nutrient digestibility and performance of beef steers fed high-roughage diets. Asian-Australas J Anim Sci 2009;22:993-1004.

10. Kim W, Gamo Y, Sani YM, et al. Effect of tween 80 on hydrolytic activity and substrate accessibility of carbohydrolase I (CBH I) from Trichoderma viride. Asian-Australas J Anim Sci 2006;19:684-9.

11.Hristov A, McAllister T, Olson M, et al. Effect of Tween 80 and salinomycin on ruminal fermentation and nutrient digestion in steers fed a diet containing 70\% barley. Can J Anim Sci 2000;80:363-72. 
12. Wang Y, Alexander TW, McAllister TA. In vitro effects of Monensin and Tween 80 on ruminal fermentation of barley grain: barley silage-based diets for beef cattle. Anim Feed Sci Technol 2004;116:197-209.

13.Zinn RA. Comparative feeding value of supplemental fat in steam-flaked corn-and steam-flaked wheat-based finishing diets for feedlot steers. J Anim Sci 1992;70:2959-69.

14. Cho HT, Salvia-Trujillo L, Kim J, et al. Droplet size and composition of nutraceutical nanoemulsions influences bioavailability of long chain fatty acids and Coenzyme Q10. Food Chem 2014;156:117-22.

15. Kurukji D, Pichot R, Spyropoulos F, Norton IT. Interfacial behaviour of sodium stearoyllactylate (SSL) as an oil-in-water pickering emulsion stabiliser. J Colloid Interface Sci 2013;409: 88-97.

16. Narsimhan G, Wang Z. Guidelines for processing emulsionbased foods. In: Hasenhuettl GL, Hartel RW, editors. Food emulsifiers and their applications. 2nd ed. New York, NY: Springer; 2008. pp. 349-94.

17. NRC. Nutrient requirements of dairy cattle. 7th ed. Washington, DC, USA: National Academy Press; 2001.

18. AOAC. Official methods of analysis. Association of Official Analytical Chemists. Arlington, VA, USA: AOAC International; 1990.

19. Van Soest PJ, Robertson JB, Lewis BA. Methods for dietary fiber, neutral detergent fiber, and nonstarch polysaccharides in relation to animal nutrition. J Dairy Sci 1991;74:3583-97.

20. Cockcroft P. Bovine medicine. 3rd ed. West Sussex, UK: WileyBlackwell; 2015.

21.Simon FP, Thomas JD. Rebhun's diseases of dairy cattle. Philadelphia, PA, USA: Saunders; 2008.

22. Korea Dairy Committee. Korean milk pricing system. Dairy statistics yearbook [internet]. Sejong, Korea: Korea Dairy Committee [cited 2013 Feb 4]. Available from http://www. dairy.or.kr

23.SAS (Statistical Analysis System) Institute Inc. SAS user's guide. 9.2th ed. Cary, NC, USA: SAS Institute Inc.; 2003.
24.Duncan DB. Multiple range and multiple F tests. Biometrics 1955;11:1-42.

25. Dierick NA, Decuypere JA. Influence of lipase and/or emulsifier addition on the ileal and faecal nutrient digestibility in growing pigs fed diets containing 4\% animal fat. J Sci Food Agric 2004; 84:1443-50.

26. Dickinson E. Flocculation of protein-stabilized oil-in-water emulsions. Colloids Surfaces B Biointerfaces 2010;81:130-40.

27. Dickinson E. Food emulsions and foams: stabilization by particles. Curr Opin Colloid Interface Sci 2010;15:40-9.

28. Nishibu J. Current status of MUN utilization in Japan. Japan: Tokachi Federation Agricultural Cooperative 1998.

29.Zinn RA, Gulati SK, Plascencia A, Salinas J. Influence of ruminal biohydrogenation on the feeding value of fat in finishing diets for feedlot cattle. J Anim Sci 2000;78:1738-46.

30. Payne JM, Dew SM, Manston R, Faulks M. The use of a metabolic profile test in dairy herds. Vet Rec 1970;87:150-8.

31. Cho H-U, Ko W-S, Son H-W, et al. Hematological and biochemical analysis of Korean indigenous cattle according to the ages. Korean J Vet Serv 2008;31:137-47.

32. Sattar A, Mirza R. Haematological parameters in exotic cows during gestation and lactation under subtropical conditions. Pak Vet J 2009;29:129-32.

33. Scamell JM. Healthy land for healthy cattle. Cattle Pract 2006; 14:143-52.

34. Mohamed GAE. Investigation of some enzymes level in blood and milk serum in two stages of milk yield daily cows at Assiut city. Assiut Vet Med J 2014;60:110-20.

35. Rivera JD, Bachman SE, Hubbert ME, et al. Short communication: serum and tissue concentrations of vitamin D metabolites in beef heifers after buccal dosing of 25-hydroxyvitamin D3. J Dairy Sci 2005;88:1364-9.

36. Kim DH, Kim KH, Nam IS, et al. Effect of indigenous herbs on growth, blood metabolites and carcass characteristics in the late fattening period of Hanwoo steers. Asian-Australas J Anim Sci 2013;26:1562-8. 